\title{
Soil Characteristics of an Abandoned Shifting Cultivation Land in Sarawak, Malaysia
}

\author{
Satoshi ISHIZUKA United Graduate School of Agricultural Science, Ehime University, Matsuyama, \\ Ehime 790-8566, Japan \\ Katsutoshi SAKURAI Faculty of Agriculture, Kochi University, Nankoku, Kochi 783-8502, Japan \\ John SABang, Joseph Jawa Kendawang \& Hua Seng LeE \\ Forest Department Sarawak, Kuching, Sarawak 93660, Malaysia
}

\begin{abstract}
Since 1996 ecosystem rehabilitation by tree planting has been carried out on the degraded land after shifting cultivation at Bakam Forest Reserve (BFR), Sarawak, Malaysia. In order to evaluate the performance of the rehabilitation of a degraded land after shifting cultivation, at first, it needs to define the current status of degraded soils. In this study, the morphological, physico-chemical, mineralogical, and charge characteristics of soils on the degraded land were investigated.

Nutrient content of soils in the degraded land was quite low at the same level as was seen in the subsurface soil of the remnant forest due to soil erosion after shifting cultivation. The soils in the degraded land were harder than those in the remnant forest due to soil compaction. The soils showed strongly weathered characteristics, such as low PZSE (Point of Zero Salt Effect) value, high proportion of variable-charge minerals due to loss of 2: 1 type clays with permanent negative charge, and low oxide contents. Soil properties become worse easily and shortly after soil erosion, and are modified by the water action and topography in situ. Once the vegetational cover is destroyed, it could not regenerate easily in such an intrinsic infertile soil condition even under enough rainfall and high temperature.
\end{abstract}

Key words: charge characteristics / degraded land / physico-chemical properties / Sarawak / shifting cultivation / soil hardness

Once natural forest is cleared, the original stocks of nutrients in soils will be exhausted severely. Soil degradation problem in the worldwide scale was reviewed in Advances in Soil Science Volume 11 (Lal \& Stewart, 1990) in detail. At present 5 to 7 million hectares of arable land (0.3\% to $0.5 \%)$ are lost every year through soil degradation (Lal \& Stewart, 1992). The expansion of agricultural land in Malaysia has been taking place on marginal soils and steep lands that are highly vulnerable to erosion (Lal, 1990). Simultaneously, the tropical forest is destroyed for agriculture and their soils are degraded rapidly.

Ultisols are the most abundant soils found in Southeast Asia (Sanchez, 1976), which have been characterized by some workers (Owen, 1951; Beckett \& Hopkinson, 1961; Wood \& Beckett, 1961; Dudal \& Moormann, 1964; Ohta \& Effendi, 1992). However, there is little information on the Ultisols under the dipterocarp forest, which has been lost by shifting cultivation. Since 1996, several types of tree planting as ecosystem rehabilitation was attempted on the degraded land in Sarawak, Malaysia (Ogino, 1999; Sakurai, 1998). To understand the rehabilitation and restoration of the degraded land through the detailed evaluation on rehabilitation process, an accumulation of knowledge on initial soil 


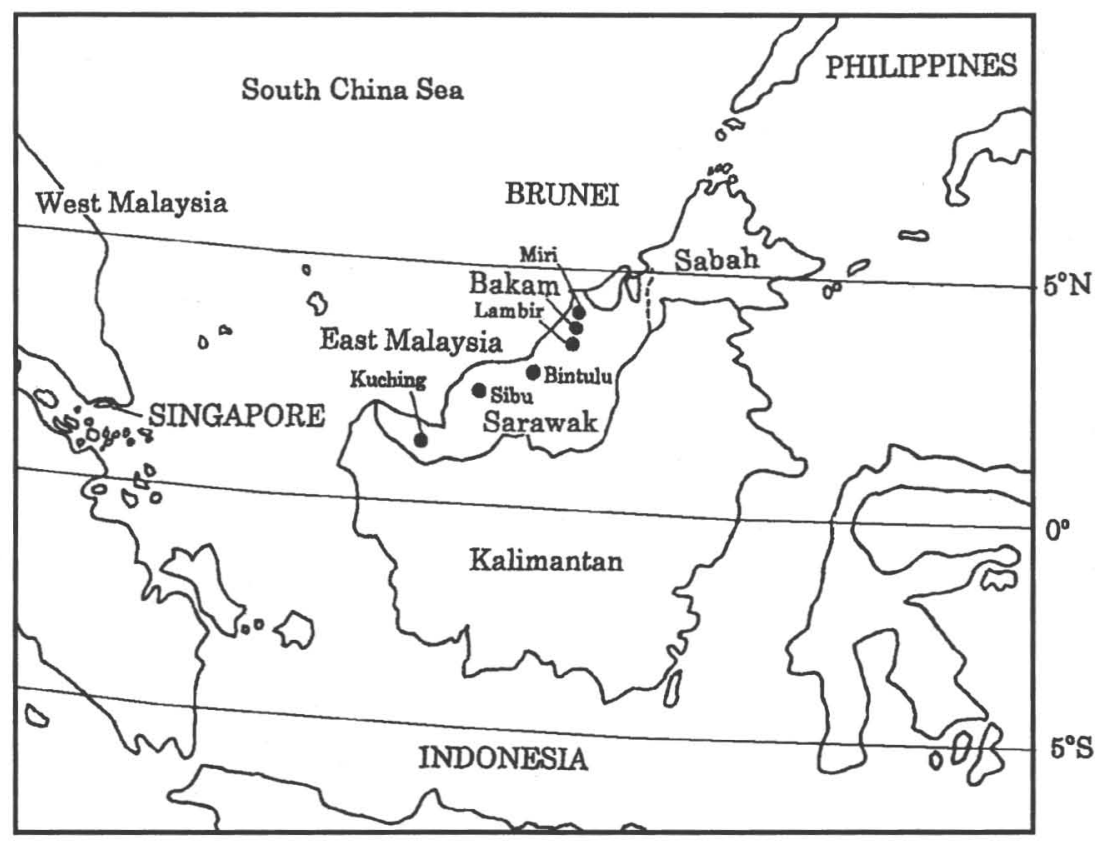

Fig. 1. Location of study site of Bakam Forest Reserve (BFR), Sarawak, Malaysia.

conditions in the degraded lands should be of prime importance. Thus, in this report, the soil condition in an abandoned shifting cultivation area was evaluated, with special reference to morphological, physico-chemical, and mineralogical properties of the soils.

\section{MATERIALS AND METHODS}

\section{Study area}

Bakam Forest Reserve (BFR) is situated along the gravel road leading to Bakam village about $6.4 \mathrm{~km}$ from Miri-Bintulu Road in Miri Division, Sarawak, Malaysia (Fig. 1). The landform of the area can generally be described as low hills with highest point of about $90 \mathrm{~m}$ in altitude. Parent materials are tertiary sedimentary rocks (sandstone and/or shale). The mean annual precipitation at Miri town (about $30 \mathrm{~km}$ north of the study site) from 1917 to 1957 was 3,150 mm (Yamakura et al., 1995). BFR is comprised of two valleys (Fig. 2). The valleys, one facing northward and the other westward are separated by a tripod ridge. Tree planting experiment for ecosystem rehabilitation of shifting cultivation areas was carried out in the BFR in 1996 to 1998. Total area of our research site in the BFR is 21.4 ha. Although an area about 0.4 ha of remnant forest was left at the northwestern portion, the area is mostly covered with secondary growth vegetation after shifting cultivation. It is dominated by light demanding shrubs and trees ranging from 3 to $6 \mathrm{~m}$ in height. The canopy is still wide open in most places. Soil survey was carried out at seven sites. The B1 site is located on a middle slope of the remnant forest, with a steep slope more than 40 degree. The B2 and B3 sites are located in the upper slope of the eastern and western side at the northward valley, respectively. The slope at the B2 site is 


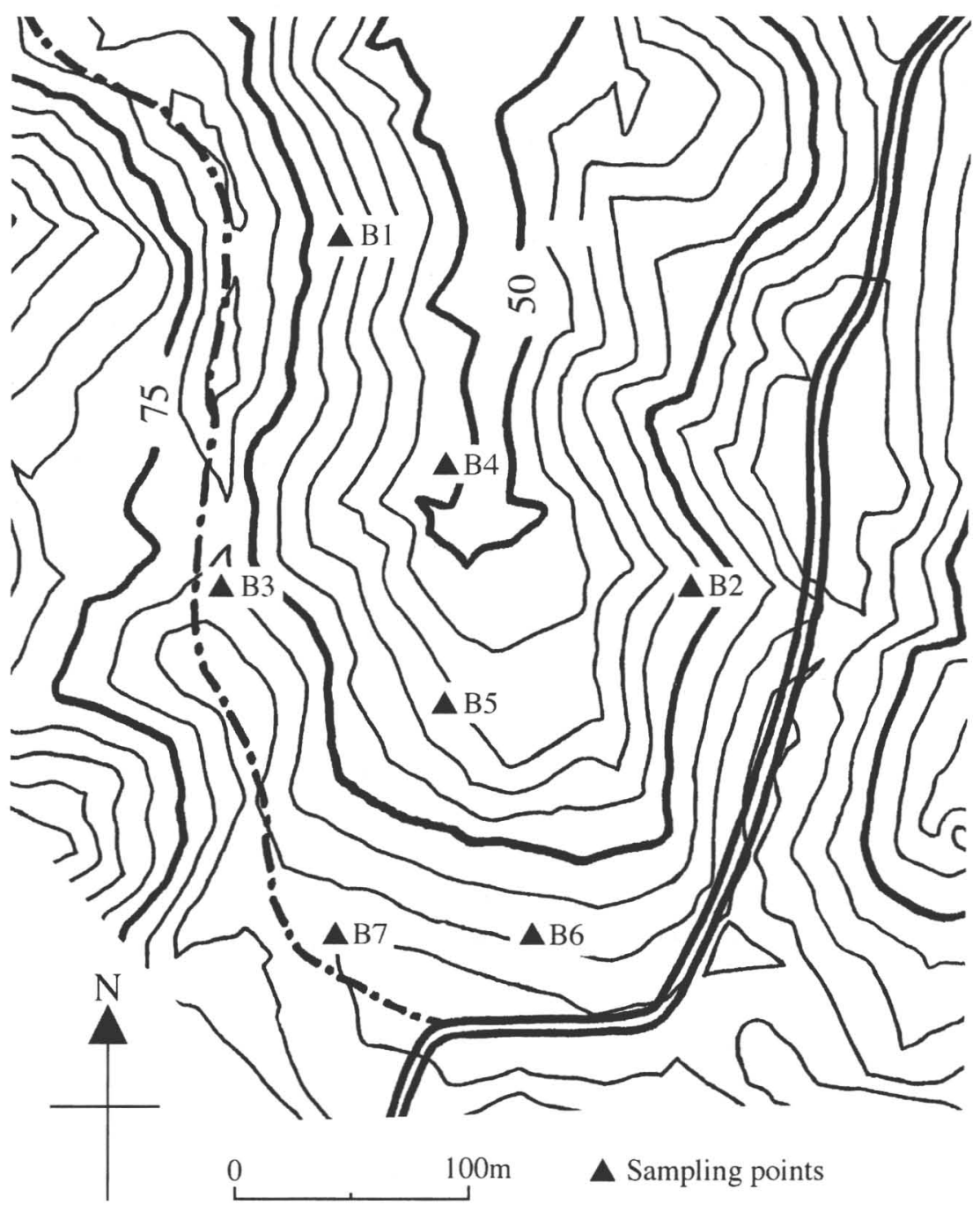

Fig. 2. Topography of Bakam Forest Reserve (BFR).

29 degree while that at the B3 site is 34 degree. Since the canopy is still wide open and the slope is very steep, a frequent heavy rainfall might have caused a severe erosion of the topsoil. Therefore, the upper part of solum was found to be unstable from the standpoint of pedogenesis. The B4 and B5 are located in a relatively stable lower slope, with a gentle slope less than 10 degree. The B4 site is partially covered by the canopy of a pioneer tree, e.g., Macaranga sp., and some ground vegetation, whereas the B5 site is covered with some weeds and shrubs (fern and imperata grass). The B6 and B7 are located in the upper part of valley. The slope at the B6 site is 25 degree while that at the B7 site is 9 degree. The B6 site is covered with light demanding shrubs and small trees, while the B7 site is no definite canopy cover. At these sites, the soil profile was prepared and described in terms of texture, soil color, soil structure, gravels, and roots, and so on (Table 1). 
Table 1. Morphological properties of the soils.

\begin{tabular}{|c|c|c|c|c|c|c|c|}
\hline $\begin{array}{l}\text { Soil } \\
\text { (Slope; degree) }\end{array}$ & $\begin{array}{l}\text { Hori- } \\
\text { zon }\end{array}$ & $\begin{array}{l}\text { Depth } \\
(\mathrm{cm})\end{array}$ & Soil color & Texture & Structure $^{\mathrm{a}}$ & \multicolumn{2}{|c|}{ Roots / stone Boundary ${ }^{b}$} \\
\hline $\begin{array}{l}\text { B1 } \\
(40)\end{array}$ & $\begin{array}{c}\mathrm{O} \\
\mathrm{A} \\
\mathrm{AB} \\
\mathrm{B} 1 \\
\mathrm{~B} 2\end{array}$ & $\begin{array}{c}16-0 \\
0-1 / 2 \\
-8 / 9 \\
-30 / 31 \\
-55+\end{array}$ & $\begin{array}{l}\text { 10YR4/ } 2 \\
\text { 10YR5/6 } \\
\text { 10YR6/ } 6 \\
\text { 10YR7/ } 6\end{array}$ & $\begin{array}{l}\mathrm{L} \\
\mathrm{CL} \\
\mathrm{CL} \\
\mathrm{SCL}\end{array}$ & $\begin{array}{c}1 \mathrm{fsbk}, 1 \mathrm{vfg} \\
1 \mathrm{fsbk} \\
1 \mathrm{fsbk} \\
1 \mathrm{fsbk}\end{array}$ & $\begin{array}{c}\text { many / none } \\
\text { common / none } \\
\text { few / none } \\
\text { few / none }\end{array}$ & $\begin{array}{l}\mathrm{CW} \\
\mathrm{CW} \\
\mathrm{CW}\end{array}$ \\
\hline $\begin{array}{l}\text { B2 } \\
(29)\end{array}$ & $\begin{array}{l}\mathrm{O} \\
\mathrm{A} \\
\mathrm{B} 1 \\
\mathrm{~B} 2\end{array}$ & $\begin{array}{c}3-0 \\
0-7 / 15 \\
-34 \\
-50+\end{array}$ & $\begin{array}{l}\text { 10YR4/3 } \\
10 \mathrm{YR} 7 / 6 \\
10 \mathrm{YR} 7 / 6\end{array}$ & $\begin{array}{l}\text { CL } \\
\text { CL } \\
\text { CL }\end{array}$ & $\begin{array}{l}1 \mathrm{msbk} \\
1 \mathrm{msbk} \\
1 \mathrm{msbk}\end{array}$ & $\begin{array}{c}\text { common / none } \\
\text { few / none } \\
\text { none / none }\end{array}$ & $\begin{array}{l}\text { aw } \\
\text { cw }\end{array}$ \\
\hline $\begin{array}{l}\text { B3 } \\
(34)\end{array}$ & $\begin{array}{c}\mathrm{O} \\
\mathrm{A} \\
\mathrm{BA} \\
\mathrm{B} 1 \\
\mathrm{~B} 2\end{array}$ & $\begin{array}{c}1-0 \\
0-7 / 10 \\
-23 \\
-31 \\
-58+\end{array}$ & $\begin{array}{l}\text { 10YR5/3 } \\
\text { 10YR6/4 } \\
10 Y R 7 / 6 \\
10 Y R 7 / 8\end{array}$ & $\begin{array}{l}\text { CL } \\
\text { SCL } \\
\text { SCL } \\
\text { SCL }\end{array}$ & $\begin{array}{l}2 \mathrm{msbk} \\
2 \mathrm{msbk} \\
2 \mathrm{msbk} \\
2 \mathrm{msbk}\end{array}$ & $\begin{array}{c}\text { common / none } \\
\text { few / none } \\
\text { few / none } \\
\text { none / none }\end{array}$ & $\begin{array}{l}\text { aw } \\
\mathrm{cw} \\
\mathrm{cw}\end{array}$ \\
\hline $\begin{array}{l}\text { B4 } \\
(10)\end{array}$ & $\begin{array}{l}\mathrm{O} \\
\mathrm{A} \\
\mathrm{B} 1 \\
\mathrm{~B} 2\end{array}$ & $\begin{array}{c}16-0 \\
0-7 / 10 \\
-30 / 35 \\
-50+\end{array}$ & $\begin{array}{l}\text { 10YR4/2 } \\
\text { 10YR7/6 } \\
10 Y R 7 / 6\end{array}$ & $\begin{array}{l}C L \\
C L \\
C L\end{array}$ & $\begin{array}{l}1 \mathrm{msbk} \\
1 \mathrm{msbk} \\
1 \mathrm{msbk}\end{array}$ & $\begin{array}{c}\text { common / none } \\
\text { few / none } \\
\text { few / none }\end{array}$ & $\begin{array}{l}\mathrm{cw} \\
\mathrm{ci}\end{array}$ \\
\hline $\begin{array}{l}\text { B5 } \\
(10)\end{array}$ & $\begin{array}{l}\mathrm{O} \\
\mathrm{A} \\
\mathrm{B} 1 \\
\mathrm{~B} 2\end{array}$ & $\begin{array}{c}3-0 \\
0-10 / 15 \\
-27 \\
-50+\end{array}$ & $\begin{array}{l}\text { 10YR4/3 } \\
10 Y R 7 / 6 \\
10 Y R 7 / 6\end{array}$ & $\begin{array}{l}\text { CL } \\
C L \\
C L\end{array}$ & $\begin{array}{l}1 \mathrm{msbk} \\
2 \mathrm{msbk} \\
2 \mathrm{msbk}\end{array}$ & $\begin{array}{l}\text { many / none } \\
\text { common / none } \\
\text { few / none }\end{array}$ & $\begin{array}{l}\mathrm{cb} \\
\mathrm{cW}\end{array}$ \\
\hline $\begin{array}{l}\text { B6 } \\
(25)\end{array}$ & $\begin{array}{l}\mathrm{O} \\
\mathrm{A} \\
\mathrm{B} 1 \\
\mathrm{~B} 2\end{array}$ & $\begin{array}{c}6-0 \\
0-5 \\
-18 / 20 \\
-50+\end{array}$ & $\begin{array}{l}\text { 10YR5/3 } \\
\text { 10YR5/6 } \\
10 Y R 7 / 6\end{array}$ & $\begin{array}{l}\text { SCL } \\
\text { SCL } \\
\text { SCL }\end{array}$ & $\begin{array}{l}1 \mathrm{msbk} \\
2 \mathrm{msbk} \\
2 \mathrm{msbk}\end{array}$ & $\begin{array}{c}\text { common / none } \\
\text { few / none } \\
\text { few / none }\end{array}$ & $\begin{array}{l}\mathrm{CW} \\
\mathrm{cW}\end{array}$ \\
\hline $\begin{array}{l}\text { B7 } \\
(9)\end{array}$ & $\begin{array}{c}\mathrm{O} \\
\mathrm{A} \\
\mathrm{C} 1 \mathrm{~g} \\
\mathrm{C} 2 \mathrm{~g}\end{array}$ & $\begin{array}{c}4-0 \\
0-9 / 11 \\
-20 / 23 \\
-50+\end{array}$ & $\begin{array}{l}\text { 10YR6/4 } \\
\text { 10YR5/8* } \\
\text { 10YR5/8* }\end{array}$ & $\begin{array}{l}\text { SCL } \\
\mathrm{CL} \\
\mathrm{LiC}\end{array}$ & $\begin{array}{c}1 \mathrm{msbk} \\
\text { no structure } \\
\text { no structure }\end{array}$ & $\begin{array}{c}\text { many / none } \\
\text { common / few } \\
\text { few / few }\end{array}$ & $\begin{array}{l}\mathrm{cW} \\
\mathrm{cW}\end{array}$ \\
\hline
\end{tabular}

a) Grade: 1, week; 2, moderate.

Class: vf, very fine; $f$, fine; $m$, medium.

Type: g, granular; sbk, subangular-blocky.

b) aw, abrupt wavy; cw, clear wavy; ci, clear irregular; cb, clear broken.

*) Reduced mottle colors of C1g and C2g horizons were 10YR7/3 and 10YR8/2, respectively.

\section{Analytical Methods}

\section{Physical properties}

To know the vertical distribution of the soil hardness, we better use a cone penetrometer equipped with a metal cone on top and a weigh to push and make the cone penetrating into soils. We just fall the $2 \mathrm{~kg}$ of weigh at a given distance $(50 \mathrm{~cm})$, and record the penetrating depth by an attached scale. Based on the reading, penetration resistance can be estimated. We conveniently use Hasegawa type cone penetrometer (Daito Green, H-60) until the depth of $60 \mathrm{~cm}$ around the soil pits. 


\section{Physico-chemical and mineralogical properties}

The analysis of the soil samples collected at the depth of 5-10 cm and $15-20 \mathrm{~cm}$ at all sites in the BFR was performed for the evaluation of soil fertility. Soil samples were air-dried and crushed to pass through a $2-\mathrm{mm}$ sieve. The $\mathrm{pH}$ was measured with a glass electrode using a soil to solution $\left(\mathrm{H}_{2} \mathrm{O}\right.$ or $1 \mathrm{M}-\mathrm{KCl}$ ) ratio of 1 : 5 after reciprocal shaking for $1 \mathrm{~h}$ (designated as $\mathrm{pHw}$ and $\mathrm{pHk}$, respectively). Electric conductivity (EC) was measured using the supernatant solution after reciprocal shaking for 1 $\mathrm{h}$ at a soil to water ratio of 1 to 5 . Exchangeable bases were extracted with $1 \mathrm{M}$ ammonium acetate at $\mathrm{pH} 7.0$ twice, using a soil to solution ratio of $1: 5$ and then the amounts of $\mathrm{Ca}, \mathrm{Mg}$ and $\mathrm{K}$ in the extract were determined by atomic absorption spectrophotometer, and that of $\mathrm{Na}$ by flame photometry (Shimadzu, AA-610S). Exchangeable $\mathrm{Al}$ and $\mathrm{H}$ were extracted with $1 \mathrm{M} \mathrm{KCl}$, and their contents were determined by the titration method. After replacement of exchangeable bases, washing with a deionized water and a $99 \%$ ethanol and replacement of $\mathrm{NH}_{4}{ }^{+}$with $10 \% \mathrm{NaCl}$ were successively performed by centrifugation. The amount of ammonium ion was determined by Kjeldahl distillation and titration method. Particle size distribution was determined by the pipette method. Total carbon and nitrogen were determined by a dry combustion method using NC-analyzer (Sumitomo Chemical, Sumigraph model NC-80). Available phosphorous was extracted with $0.001 \mathrm{M} \mathrm{H}_{2} \mathrm{SO}_{4}$ (Truog method) and its content was determined by the molybdenum blue method. $\mathrm{Al}, \mathrm{Fe}$, and $\mathrm{Si}$ oxides were extracted twice with an acid ammonium oxalate solution $(0.2 \mathrm{M}, \mathrm{pH} 3.0)$ by reciprocal shaking in the dark for 1 h, at a soil to solution ratio of 1 to 25 (Mckeague \& Day, 1966). They were extracted twice with a citrate-bicarbonate mixed solution buffered at $\mathrm{pH} 7.3$ with the addition of sodium dithionite for 15 min. at 75 to $80{ }^{\circ} \mathrm{C}$, using a soil to solution ratio of 1 to 100 (Mehra \& Jackson, 1960). Al, Fe, and Si contents in the extract were designated as Alo, Feo, and Sio for the former extractant, and Ald, Fed, and Sid for the latter. The contents of all the cations were determined using a sequential plasma spectrometer (Shimadzu, ICPS-1000IV). Clay minerals were identified by X-ray diffraction method (Shimadzu, XD-D1w). Point of zero salt effect (PZSE) and op value of soils was determined by a modified salt titration (STPT) method (Sakurai et al., 1988).

\section{RESULTS AND DISCUSSION}

\section{Soil morphological characteristics}

Generally, red yellow podzolic soils by the Malaysian soil taxonomy (Theng, 1993) equivalent to Acrisols (FAO/UNESCO, 1974) or Ultisols (Soil Survey Staff, 1992) were found in the BFR. The soil profile descriptions are shown in Table 1. At the B1 (remnant forest) and B4 sites, the O layer was thick because of accumulation of organic materials, while the O layer at the other sites was thin and mostly consisted of dead weeds. At the B1 site, the root mat $(<10 \mathrm{~cm}$ in thick) was well-developed. On the other hand, at the other sites, only grass roots were found in the surface horizon and some carbonized tree roots remained in the deeper part of solum. There could be seen parent rocks (slightly to moderately weathered sandstone) in the subsurface layer (20-23 cm in depth) at the B7 site, whereas at the other sites, parent rocks could not be seen within the profile examined. Although most of the sites showed a very sandy texture in the surface A horizon in the BFR, the most significant difference among sites was the color and thickness of A horizon. In the B1 pedon on a middle slope in the remnant forest, surface A horizon was only 1-2 cm in thickness except for root mat with a grayish 
yellow brown color of 10YR4/2. On the other hand, in the other pedons, the thickness of A horizons were 7-15 cm, 7-10 cm, 10-15 cm, $5 \mathrm{~cm}$, and 9-11 cm for B2, B3 and B4, B5, B6, and B7, respectively. The surface A horizons had various colors of dull yellowish brown (10YR4/3 for B2 and B5, 10YR5/3 for B3 and B6), grayish yellow brown (10YR4/2 for B4), and dull yellow orange (10YR6/4 for B7). The surface A horizon of these soils tended to be higher hue and value in color than that of the B1 in the remnant forest. Erosivity depends on the physical characteristics of rainfall: the size of the drops, their number per unit time, their velocity, and the resulting kinetic energy they carry. Tropical rains have larger drops than temperate rains. In general, the greater the rain intensity, the greater the proportion of large drops and the faster their terminal fall velocities (Van Wambeke, 1992). For these reasons, a frequent heavy rainfall might have caused a severe erosion of surface soils, and therefore, subsurface soils became a current surface layer. The difference in color and thickness of surface horizon might be brought about by the relative accumulation of organic materials in the BFR. If the soil is exposed to the bombarding force of raindrops, the aggregates tend to break apart, and the detached particles are subject to movement in the runoff water (Harpstead et al., 1988). However, subangular blocky structure at surface soils was observed at the survey sites. Once the soil surface is covered with the weeds and some pioneer trees for several decades, the destruction of soil structure and soil erosion may be prevented. In the B7 site, the deeper horizons (C1 and C2) had reduced mottles, indicating a wet condition.

These soils can be classified into the following Sarawak soil series (Theng, 1993);

B1, B2, B5 and B6: Bekenu series

B3: Nyalau series

B4: Merit series

B7: Stom series

According to Sabang et al. (1998), Bekenu series are the fine loamy red yellow podzolic group with color hue of $10 \mathrm{YR}$ within $50 \mathrm{~cm}$ of the surface. The Nyalau series are the coarse loamy red yellow podzolic group that has developed from sandstone. It is one of the dominant soils in the BFR. The Merit series are the clayey texture soils. It is derived from argillaceous sedimentary rock, mainly shale. Shale fragments are commonly found in the subsoil. The profile of the Bekenu, Nyalau and Merit series have a brownish yellow A horizon over a yellow B horizon. The Stom series are also of the clayey soils and similar to Merit series except for a lower value and chroma of soil color. This is because of the poor drainage within $50 \mathrm{~cm}$ of soil surface.

Geologically, the distribution of parent materials, namely sandstone and/or shale, is complicated because of a tilt and a fault. When sandstone and shale appear on the ground, soils are sandy and clayey texture, respectively. Thus, the existence of different soil series among a relatively small area would be related to the presence of the parent materials on the ground surface. The distribution of soils here, therefore, could be depending on the distribution of parent materials in situ strongly affected by the topographic factor.

Lambir Hills National Park (LHNP) which is located about $20 \mathrm{~km}$ south of BFR is covered with mixed dipterocarp forest. Since the LHNP is protected against fire and any sort of activities and its canopy of mixed dipterocarp forest is maintained, a continuous supply of organic matter and its accumulation in soils can be found, which may contribute to the prevention of soil erosion except for steep slope area. According to the soil profile description in LHNP (Ishizuka et al., 1998), on a stable 


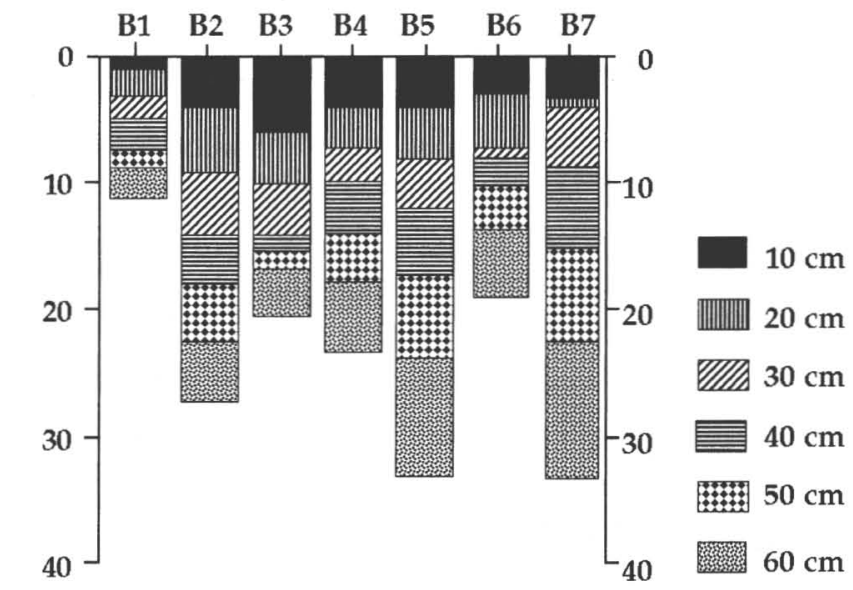

Counts

Fig. 3. Counts for penetrating $60 \mathrm{~cm}$ by soil penetrometer.

hill ridge, the root mat was well-developed on the surface and soil depth was deeper than $200 \mathrm{~cm}$ without any presence of gravel in the pedon. On the lower slope near valley bottom, the root mat was not developed and soil depth was shallow. In addition, coarse fragments in subsurface horizon were abundant because transported materials can be supplied from the surroundings continuously.

Now we try to compare the BFR and the LHNP in terms of five major factors for soil genesis, i.e., parent materials, topography, biology, time, and climate. Biologically, there would be clear differences reflecting the amount of organic matter accumulation. Since both of the sites were located within a relatively short distance (about $20 \mathrm{~km}$ apart from each other), there may not be a definite difference in climate and geological time for long-term weathering. The soil materials found in both plots were the weathering products of sandstone and shale. Therefore, the difference between the two sites mostly could be caused by the human activity. Once the vegetation is removed by some human activities, i.e., shifting cultivation, it is difficult to recover the vegetation because of the erosion of surface soils with a high nutrient content. The current status of soils in the BFR and the LHNP is very different in morphology of surface soils, which can be one of the influential factors to cause the difference in vegetation.

\section{Physical properties}

The analysis of soil hardness enables us to seize the material distribution in soils, where most of the roots concentrate (Hasegawa et al., 1984; Sakurai et al., 1995). In particular, gravel layer can be easily discriminated without digging a soil pit and without disturbing the vegetation stand greatly (Sakurai $e t$ $a l .$, 1995). If a gravel layer is found in a shallow depth, tree root may suffer greatly from the physical hazard.

Examples of the vertical distribution of soil hardness around the soil pit are depicted for each site (Fig. 3). At the B1 in the remnant forest, the soil was very soft, especially, at the surface soil, where the roots concentrate. No gravel layer and bedrock appeared down to the depth of $60 \mathrm{~cm}$. This pattern 
of soil hardness distribution is similar to that of the ridge part in the natural forest as shown by Ishizuka et al. (1998). Total counts of soil hardness measurement at the B2 and B3 on the upper slope was slightly higher than that at the B1. Soil compaction was caused by the elimination or reduction of structural pores. Increase in soil bulk density is caused by natural and man-induced factors. Hardsetting is a problem in soils of low-activity clays and soils that contain low organic matter content (Lal \& Stewart, 1990). Destruction of organic matter by fire destroys the soil structure and reduces porosity, which decreases infiltration and increases runoff and erosion (DeBano et al., 1998). Thus, the B2 and B3 soils that were located on very steep slope could be compacted due to loss of organic matter and erosion of surface soils during and after burning. At the B4 and B5, the soils were slightly harder than the soils on the upper slope, and it became harder gradually with depth, indicating the presence of the finer soil materials at deeper part of soils. The B6 soil was softest in the degraded shifting cultivation area except the remnant forest soil (B1) because the B6 was located on the upper part of valley and was in a wet condition. Although the B7 was also located on the upper part of valley, soil hardness at the $\mathrm{B} 7$ was higher than that at the $\mathrm{B} 6$, representing the presence of some rock fragment. Material distribution estimated through soil hardness measurement was confirmed by the profile description (Table 1).

Compared with the LHNP, the soil hardness in the BFR tended to be slightly harder, because of the compaction of subsurface soils and the absence of organic matter. According to the results of soil hardness in the two major types of forest, i.e., dry evergreen forest and dry dipterocarp forest in northeast Thailand (Sakurai et al., 1998), the soils were very hard except the surface horizon due to the presence of the gravel layer and high contents of clay particles. Total counts of soil hardness measurement were sometimes more than 150 (Sakurai et al., 1998), whereas total counts in the BFR were less than 40 . This suggests that the physical stress of soil hardness against root elongation in the BFR was much lower than the soils in the northeast Thailand. The root of an elm (Zelkova serrata) cannot elongate well, when the value of the penetrating depth $(\mathrm{cm})$ per one drop of weigh is less than 0.5 (Hasegawa et al., 1984). The physical hazard of soil hardness for root elongation was not confirmed in the BFR. However, the surface soils will become harder when there is no rain for a few days, because the canopy is still wide open in the BFR, and therefore, soil moisture is prone to fluctuate easily.

We can now conclude that the prediction of the distribution of soil materials in the BFR can be accomplished successfully by the simple technique using a soil penetrometer, and a serious hazard due to soil compaction could not be found here.

\section{Physico-chemical and mineralogical properties}

The results of soil analysis are summarized in Tables 2 and 3. Sand content was higher than $75 \%$ for all the soils, indicating that parent materials were mainly consisted of sandstone. There was no significant difference in particle size distribution among the sites. Based on these data, the weathering status of parent materials seemed to be rather strong due to the absence of silt fraction (0.6-2.8\%). The soils in the BFR were strongly acid with $\mathrm{pHw}$ and $\mathrm{pHk}$ values below 5.1 and 4.1, respectively, due to the presence of exchangeable $\mathrm{Al}$ and $\mathrm{H}$. The level of available phosphorus in the BFR soils was extremely low even in the remnant forest, ranging from 0.69 to $7.17 \mathrm{mg} \mathrm{kg}^{-1}$. The value of electric conductivity (EC), the amounts of exchangeable $\mathrm{Mg}$ and $\mathrm{K}$, total $\mathrm{N}$ and $\mathrm{C}$, and cation exchange 
Table 2. Soil chemical and physical properties.

\begin{tabular}{|c|c|c|c|c|c|c|c|c|c|c|c|c|c|c|c|c|c|}
\hline \multirow{3}{*}{$\begin{array}{l}\text { Soil } \\
\mathrm{B} 1\end{array}$} & \multirow{3}{*}{$\begin{array}{l}\text { Depth } \\
(\mathrm{cm}) \\
5-10\end{array}$} & \multirow{2}{*}{$\begin{array}{l}\mathrm{EC}^{\star} 1 \\
\left(\mathrm{dS} \mathrm{m}^{-1}\right)\end{array}$} & \multirow{2}{*}{$\mathrm{pH}_{\mathrm{w}}$} & \multirow[t]{2}{*}{$\mathrm{pH}_{\mathrm{k}}$} & \multicolumn{5}{|c|}{ Exchangeable cations } & \multirow[b]{2}{*}{$\mathrm{H}$} & \multicolumn{2}{|c|}{$\mathrm{CEC}^{\star 2}$ Available } & \multicolumn{2}{|c|}{ Total } & \multicolumn{3}{|c|}{ Particle size distribution } \\
\hline & & & & & $\mathrm{Ca}$ & $\mathrm{Mg}$ & K & $\mathrm{Na}$ & $\mathrm{Al}$ & & & 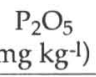 & & $\begin{array}{c}\mathrm{N} \\
\left.\mathrm{kg}^{-1}\right)\end{array}$ & Clay & & \\
\hline & & 0.046 & 4.76 & 3.75 & 0.03 & 0.78 & 0.18 & 0.01 & 3.10 & 0.38 & 9.56 & 7.17 & 38.1 & 2.10 & & & 80.9 \\
\hline & $15-20$ & 0.040 & & & 0.02 & 0.39 & & & & & & & 27.7 & & & & 0.2 \\
\hline \multirow[t]{2}{*}{ B2 } & & 0.034 & & & 0.92 & 0.67 & 0.20 & 0.0 & & 0.28 & 8.7 & $3 .($ & 15.7 & & & & 9.3 \\
\hline & $15-20$ & 0.024 & 5.02 & 4.03 & 0.22 & 0.24 & 0.13 & 0.00 & 2.01 & 0.31 & 5.98 & 2.22 & 8.04 & 0.69 & & 1.6 & 81.0 \\
\hline \multirow[t]{2}{*}{ B3 } & & 0.029 & 4.80 & & 0.07 & 0.32 & 0.1 & 0.0 & 3.72 & 0.41 & 3.3 & 2.0 & 9.33 & 0. & & 9 & 5.2 \\
\hline & $15-20$ & 0.023 & 4.98 & & 0.12 & 0.37 & 0.1 & 0.0 & & 0.33 & 7.3 & 1. & 5.96 & 0.61 & & 9 & 73.8 \\
\hline \multirow[t]{2}{*}{ B4 } & -10 & 0.033 & 4.71 & 80 & .16 & 0.21 & 0.13 & 0.00 & 2.94 & 0.37 & 7.81 & 2.20 & 12.4 & 0.85 & & 2.8 & 82.1 \\
\hline & & .026 & 4.83 & & 05 & 0.09 & & & & 0.25 & 6.7 & 2. & 8.33 & 0.71 & & & 81.4 \\
\hline \multirow[t]{2}{*}{ B5 } & $5-10$ & 0.040 & 4.96 & 3.95 & 0.88 & 0.50 & 0.21 & 0.00 & 2.18 & 0.30 & 9.35 & 2.81 & 18.1 & 1.07 & & 1.9 & 78.2 \\
\hline & & 0.036 & 4.81 & & 0.33 & 0.29 & & & & 0.29 & 8.12 & 2.17 & 13.6 & 0.95 & & & 76.2 \\
\hline \multirow[t]{2}{*}{ B6 } & & 0.036 & 4.77 & & 0.05 & 0.29 & & & & 0.39 & 6.89 & 2.09 & 13.2 & 0.87 & & .6 & 84.3 \\
\hline & $15-20$ & 0.030 & 4.75 & 397 & 0.12 & 0.16 & 0.08 & & 1.96 & 0.30 & 6.00 & 2.05 & 10.2 & 0.79 & 14 & 1.7 & 84.0 \\
\hline \multirow[t]{2}{*}{ B7 } & & 0.028 & 4.80 & & & 0.15 & 0.07 & 0.00 & 2.15 & 0.29 & 6.45 & 1.34 & 7.88 & 0.65 & 16.5 & 1.4 & 82.1 \\
\hline & $15-20$ & 0.016 & 4.97 & 4.07 & 0.23 & 0.10 & 0.05 & 0.00 & 1.19 & 0.22 & 3.32 & 0.69 & 3.77 & 0.46 & 10.1 & 0.6 & 89.3 \\
\hline
\end{tabular}

*1) Electric conductivity, ${ }^{*}$ 2) Cation Exchange Capacity

Table 3. Charge characteristics, sesquioxide properties and clay mineral composition.

\begin{tabular}{|c|c|c|c|c|c|c|c|c|c|c|c|c|c|c|c|c|c|}
\hline \multirow{2}{*}{\multicolumn{2}{|c|}{$\begin{array}{r}\text { Soil Depth } \\
(\mathrm{cm})\end{array}$}} & \multirow{3}{*}{$\begin{array}{l}\text { Alo } \\
\ldots \ldots . . . . \\
0.27\end{array}$} & \multirow{3}{*}{$\begin{array}{c}\text { Feo } \\
0.17\end{array}$} & \multirow{3}{*}{$\begin{array}{c}\text { Sio } \\
0.02 \\
0 . . . \\
\end{array}$} & \multirow{3}{*}{$\begin{array}{l}\text { Ald } \\
\text { 6) } \cdots \cdots \\
0.32 \\
0.32\end{array}$} & \multirow{3}{*}{$\begin{array}{c}\text { Fed } \\
0.39 \\
0.3\end{array}$} & \multicolumn{3}{|c|}{ Sid Alo/Ald Feo/Fed } & \multirow{2}{*}{ PZSE } & \multirow{2}{*}{$\begin{array}{c}\sigma_{\mathrm{p}} \\
\left.\mathrm{ol}(+) \mathrm{kg}^{-1}\right)\end{array}$} & \multicolumn{6}{|c|}{ Clay mineral composition ${ }^{*} 1$} \\
\hline & & & & & & & .............. & & & & & HIV. & It. & $\mathrm{Kt}$. & Lp. & Gb. & Gt. Qz. \\
\hline \multirow[t]{2}{*}{$\mathrm{Bl}$} & $5-10$ & & & & & & 0.12 & 0.83 & 0.43 & 3.81 & 0.80 & + & + & +++ & & + & + \\
\hline & $15-20$ & 0.40 & 0.17 & 0.06 & 0.44 & 0.45 & 0.11 & 0.91 & 0.38 & 4.10 & 0.77 & & + & +++ & & + & + \\
\hline \multirow[t]{2}{*}{ B2 } & $5-10$ & 0.09 & 0.16 & 0.00 & 0.15 & 0.41 & 0.05 & 0.59 & 0.39 & 4.02 & 0.11 & & ++ & & - & - & ++ \\
\hline & $15-20$ & 0.08 & 0.14 & 0.00 & 0.14 & 0.41 & 0.01 & 0.56 & 0.34 & 3.83 & 0.56 & + & + & +++ & - & - & + \\
\hline \multirow[t]{2}{*}{ B3 } & 5-10 & 0.11 & 0.20 & 0.00 & 0.18 & 0.50 & 0.07 & 0.59 & 0.40 & 3.67 & 1.47 & + & + & +++ & & - & + \\
\hline & $15-20$ & 0.10 & 0.19 & 0.00 & 0.18 & 0.55 & 0.02 & 0.54 & 0.35 & 3.87 & 0.84 & + & + & +++ & - & - & + \\
\hline \multirow[t]{2}{*}{ B4 } & 5-10 & 0.10 & 0.22 & 0.00 & 0.14 & 0.40 & 0.02 & 0.69 & 0.53 & 4.01 & 0.61 & + & + & +++ & - & + & + \\
\hline & $15-20$ & 0.10 & 0.21 & 0.00 & 0.16 & 0.44 & 0.00 & 0.65 & 0.48 & 4.21 & 0.22 & - & + & +++ & - & - & + \\
\hline \multirow[t]{2}{*}{ B5 } & $5-10$ & 0.10 & 0.27 & 0.00 & 0.15 & 0.64 & 0.05 & 0.68 & 0.42 & 4.04 & 0.94 & + & ++ & ++ & - & - & + \\
\hline & $15-20$ & 0.11 & 0.31 & 0.00 & 0.15 & 0.75 & 0.03 & 0.68 & 0.41 & 3.95 & 0.85 & + & ++ & ++ & - & - & ++ \\
\hline \multirow[t]{2}{*}{ B6 } & $5-10$ & 0.06 & 0.22 & 0.00 & 0.11 & 0.48 & 0.05 & 0.57 & 0.47 & 3.70 & 1.23 & - & + & +++ & - & - & ++ \\
\hline & $15-20$ & 0.07 & 0.22 & 0.00 & 0.12 & 0.51 & 0.02 & 0.59 & 0.44 & 3.90 & 0.92 & - & + & ++ & - & - & ++ \\
\hline \multirow[t]{2}{*}{ B7 } & $5-10$ & 0.06 & 0.31 & 0.00 & 0.16 & 1.26 & 0.03 & 0.36 & 0.24 & 3.71 & 0.96 & + & ++ & + & - & - & ++ \\
\hline & $15-20$ & 0.03 & 0.14 & 0.00 & 0.11 & 0.80 & 0.00 & 0.23 & 0.18 & 3.70 & 0.97 & + & ++ & +++ & - & + & + \\
\hline
\end{tabular}

*1),$- 0-5(\%) ;+, 5-20 ;++, 20-40 ;+++, 40-60$.

HIV., Hydroxy-interlayered vermiculite; It., Illite; Kt., Kaolinite; Lp., Lepidocrocite; Gb., Gibbsite; Gt., Geothite; Qz., Quartz.

capacity $(\mathrm{CEC})$ were relatively higher in the surface soil $(5-10 \mathrm{~cm})$ than subsurface soil $(15-20 \mathrm{~cm})$ for the B1 soil (remnant forest). Surface soil is always covered by the humus all the year from the vegetation cover at the B1. Furthermore, because of water deficiency for some period of a year, the root mat develops on the surface layer resulting in high carbon content, which also could be a cause of acidity. On the other hand, the content of the nutrients for the other soils was at the same level as was seen in the subsurface soil of the B1 site. This means the surface soils have been lost through the soil erosion after shifting cultivation. Although topography is quite different between the sites, there was no clear difference in the chemical characteristics among the sites except for the B1 soil, suggesting that the available nutrients cannot stay in the surface soils unless the canopy cover present. In the LHNP, the value of EC, exchangeable cations, total $\mathrm{C}$ and $\mathrm{N}$, and available $\mathrm{P}$ were high only in the surface horizon (Ishizuka et al., 1998; Hirai et al., 1997). It has been generally recognized that the 
bulk of organic matter and nutrients is distributed in a shallow top layer in most soils in the humid tropics (Burnham, 1984). Ohta \& Effendi (1992) reported that total amount of C, and total and available $\mathrm{N}$ and $\mathrm{P}$ stored in soils $(0-150 \mathrm{~cm}$ depth) under Lowland dipterocarp forest in Indonesia varied widely depending on the soil texture, and that fine soils stored larger amounts of $\mathrm{C}$, and total and available $\mathrm{N}$ and $\mathrm{P}$ which were distributed more largely in the subsoils $(30-150 \mathrm{~cm})$ than it has been believed. However, the soils in the BFR have very sandy texture. It was considered that the proportion of surface storage to the total was higher in the BFR soils. Once the original vegetation is removed by the human impact, the soils of the mixed dipterocarp forest may be easily degraded mostly due to soil erosion caused by a heavy rainfall throughout a year. This would be the main reason for the poor regeneration of the vegetation at the shifting cultivation area.

The values of $\mathrm{Al}$ and $\mathrm{Fe}$ extracted with acid-oxalate (Alo and $\mathrm{Feo}$ ) in the B1 soil were higher than those in the other soils (Table 3). The B1 soil under the remnant forest still received a significant amount of organic matter, which can stabilize the free $\mathrm{Fe}$ and $\mathrm{Al}$ as in the form of oxides. On the other hand, as the other soils in the BFR were almost devoid of a clay and organic fraction, Alo and Feo were very low values of less than $0.11 \%$ and $0.31 \%$, respectively, indicating the absence of active aluminum and iron oxides. The B4 and B5 soils in a relatively stable lower slope showed slightly higher Alo and Feo values than the B2 and B3 soils on the upper slope, resulting in slightly higher $\mathrm{Alo} / \mathrm{Ald}$ and $\mathrm{Feo} / \mathrm{Fed}$ ratios. The factor of the weathering and the leaching of amorphous fraction of these elements may be smaller in the relatively stable area than in the upper slope area. The B6 was located in the upper part of valley. However, the reductive condition could not be observed in the profile (Table 1), mainly due to the steep slope (25 degree) and the sandy texture. The values of Alo, Feo, Ald and Fed were within an intermediate range of oxide content between at the upper slope area (B2 and B3) and a relatively stable area (B4 and B5). Because of the reductive condition in the subsurface layers, Fe oxides can be easily dissolved. This dissolved Fe might move upward in the pedon during dry period and then could be oxidized and accumulated in the surface horizon. These processes could only be possible at the relatively stable position of the slope against soil erosion. Thus the lower Feo/Fed ratio at B7 site can be assumed to be accomplished as a secondary formation of soil weathering.

Many tropical soils are dominated by variable-charge minerals (Oades et al., 1989). Kaolinite was the dominant clay minerals for all soils, and illite was relatively rich, whereas hydroxy-interlayered vermiculite (abbreviated to HIV hereafter) was not dominant. The term "HIV" is used in this paper according to Barnhisel \& Bertsch (1989). HIV is considered to occur in soils as either weathering products derived from chlorite weathering (Ross et al., 1982) or more commonly from the deposition of hydroxy-Al polymeric components within the interlayer spaces of vermiculite (Jackson, 1962). Since we could not find any chlorite in our samples, the secondary formation of HIV in acid soil system is more probable, as suggested by Jackson (1962). In the previous paper (Ishizuka et al., 1998), at the stable hill ridge in the LHNP, clay minerals were mostly HIV with a significant amount of kaolinite. The rate and amount of dispersion of a soil varies with its clay mineral composition. Arora \& Coleman (1979) found that sodium-saturated clay minerals differed in their sensitivity to flocculation by $\mathrm{NaHCO}_{3}$ in the following order: illite > vermiculite $>$ montmorillonite $>$ kaolinite. It was considered that, at the BFR, HIV was removed out selectively in the event of soil erosion.

The PZSE value of the soils here was not high enough to be named as "strongly weathered soils", 
although the op value had already become smaller. This is the specific characteristics of the Ultisols distributing widely in the Southeast Asia. Sakurai et al. $(1988,1996)$ and Sakurai (1990) reported similar results for Thai Ultisols. Compared with the Brazilian Oxisols, the PZSE value of Thai Ultisols was lower by 1-2 $\mathrm{pH}$ unit mostly because of the presence of 2: 1 type clay minerals, although its amount was quite small. This means that, upon further weathering, 2: 1 type clay minerals would be completely lost from the soil and the relative accumulation of $\mathrm{Fe}$ and $\mathrm{Al}$ oxides would be promoted. Taking into consideration of this phenomenon, the loss of HIV due to soil erosion may accelerate the soil weathering of the Ultisols at the BFR. Further weathering should lead to the low nutrient retention holding capacity, i.e., lead to the formation of chemically poorer soils. This prevention of soil erosion by means of ecosystem rehabilitation, therefore, will cause a conservation of the soils both physically and chemically.

ACKNOWLEDGEMENTS We would thank the Forest Department Sarawak for their kind permission to participate in their joint project in Sarawak, and making this study possible. The authors would also like to thank Ms Halipah Bujang in Soil Research Center, Forest Department Sarawak, for her assistance in field sampling as well as scientific advice.

\section{REFERENCES}

Arora, H. S. \& Coleman, N. T. 1979. The influence of electrolyte concentration on flocculation of clay suspensions. Soil Sci. 127: 134-139.

Barnhisel, R. I. \& Bertsch, P. M. 1989. Chlorites and hydroxy-interlayered vermiculite and smectite. In : Dixon, J. B. \& Weed, S. B. (eds.), Minerals in Soil Environments. 2nd ed., 729-788. Soil Science Society of America, Madison, Wisconsin.

Beckett, P. H. T. \& Hopkinson, D. 1961. Some Sarawak soils. I. Soils of the region centred on the Usun Apau plateaux. J. Soil Sci. 12: 41-52.

Burnham, C. P. 1984. The forest environment: soil. In: Whitmore, T. C. (ed.), Tropical Rain Forest of the Far East, p. 148. Clarendon Press, Oxford.

DeBano, L. F., Neary, D. G., \& Ffolliott, P. F. 1998. Fire's Effects on Ecosystems, 333 pp. John Wiley \& Sons, Inc., New York.

Dudal, R. \& Moormann, F. R. 1964. Major soils of Southeast Asia. J.Trop. Geogr. 18: 54-80.

FAO/UNESCO (1974). Soil Map of the World Vol. 1, 59 pp. Legend. Unesco, Paris.

Harpstead, M. I., Hole, F. D., \& Bennett, W. F. 1988. Soil Science Simplified. 2nd. ed., pp. 123-138. Iowa State University Press, Iowa.

Hasegawa, S., Tabata, M., Kozawa, T., \& Sato, Y. 1984. Relationship between physicality of soil and tree vigour in planting area made by heavy construction machine; An example of high way planting area. J. Japanese Institute Landscape Architects 48: 104-122. (In Japanese with English summary)

Hirai, H., Matsumura, H., Hirotani, H., Sakurai, K., Ogino, K., \& Lee, H. S. 1997. Soils and the distribution of Dryobalanops aromatica and D. lanceolata in mixed dipterocarp forest. - A case study at Lambir Hills National Park, Sarawak, Malaysia. Tropics 7 (1/2): 21-33.

Ishizuka, S., Tanaka, S., Sakurai, K., Hirai, H., Hirotani, H., Ogino, K., Lee, H. S., \& Kendawang, J. 
J. 1998. Characterization and distribution of soils at Lambir Hills National Park in Sarawak, Malaysia, with special reference to soil hardness and soil texture. Tropics 8(1/2): 31-44.

Jackson, M. L. 1962. Interlayering of expansible layer silicates in soils by chemical weathering. Clays Clay Miner. 11: 29-46.

Lal, R. 1990. Soil Erosion and Land Degradation: The Global Risks. In: Lal, R. \& Stewart, B. A. (eds.), Soil Degradation, Advances in Soil Science 11: 129-172. Springer-Verlag New York Inc., New York.

— \& Stewart, B. A. 1990. Soil Degradation: A Global Threat. In: Lal, R. \& Stewart, B. A. (eds.), Soil Degradation, Advances in Soil Science 11: xiii-xvii. Springer-Verlag New York Inc., New York.

\& Stewart, B. A. 1992. Need for Land Restoration. In: Lal, R. \& Stewart, B. A. (eds.), Soil Restoration, Advances in Soil Science 17: 1-11. Springer-Verlag New York Inc., New York.

Mckeague, J. A. \& Day, J. H. 1966. Dithionite- and oxalate-extractable Fe and $\mathrm{Al}$ as aids in differentiating various classes. Can. Jour. Soil Sci. 46: 13-22.

Mehra, O. P. \& Jackson, M. L. 1960. Iron oxide removal from soils and clays by a dithionite-citrate system buffered with sodium bicarbonate. Clays Clay Miner. 7: 317-327.

Oades, J. M., Gillman, G. P., \& Uehara, G. 1989. Interactions of soil organic matter and variablecharge clays. In: Coleman, D. C., Oades, J. M., \& Uehara, G. (eds.), Dynamics of Soil Organic Matter in Tropical Ecosystems, 69-95. NifTAL Project, Department of Agronomy and Soil Science, College of Tropical Agriculture and Human Resources, University of Hawaii.

Ogino, K. 1999. Long term ecological research of tropical rain forest, Sarawak, Malaysia, with special reference to ecosystem rehabilitation of abandoned areas of shifting cultivation at Bakam Experimental Forest Reserve, 1995-99. Proceedings of the International Symposium on "Can Biological Production Harmonize with Environment? - Reports from Research Sites in Asia -", 429-431. The United Nations University, Tokyo, Japan, October 19-20, 1999.

Ohta, S. \& Effendi, S. 1992. Ultisols of "Lowland Dipterocarp Forest" in East Kalimantan, Indonesia. II. Status of carbon, nitrogen, and phosphorus. Soil Sci. Plant Nutr. 38 (2): 171-182.

Owen, G. 1951. A provisional classification of Malayan soils. J. Soil Sci. 2: 20-45.

Ross, G. J., Wang, C., Ozkan, A. I., \& Rees, H. W. 1982. Weathering of chlorite and mica in a New Brunswick podzol developed on till derived from chlorite-mica schist. Geoderma 27: 255-267.

Sabang, J., Bujang, H., \& Sakurai, K. 1998. Detailed soil survey of tree planting area (line, nest, and patch planting) at Bakam Experimental Forest Reserve. Soil Research Unit, Forest Research Center, Forest Department, Kuching.

Sakurai, K. 1990. Changes in zero point of charge (ZPC) in the weathering process of soil material. Pedologist 34 (1): 2-14. (In Japanese with English summary)

- 1998. Experimental rehabilitation of the ecosystem at Bakam Forest Reserve, Sarawak, Malaysia. Chikyu-Kankyo 3(1/2): 43-53. (In Japanese with English summary)

— Kozasa, S., Puriyakorn, B., Preechapanya, P., Tanpibal, V., Muangnil, K., \& Prachaiyo, B. 1996. Mineralogical and physico-chemical properties of four Thai soils with special reference to specific surface area (SSA) and zero point of charge (ZPC). Soil Sci. Plant Nutr. 42 (1): 93-103.

— Ohdate, Y., \& Kyuma, K. 1988. Comparison of salt titration and potentio-metric titration methods for the determination of zero point of charge (ZPC). Soil Sci. Plant Nutr. 34 (2): 171-182. 
—, Puriyakorn, B., Preechapanya, P., Tanpibal, V., Muangnil, K., \& Prachaiyo, B. 1995. Improvement of biological productivity in degraded lands in Thailand, III. Soil hardness measurement in the field. Tropics 4 (2/3): 151-172.

— Tanaka, S., Ishizuka, S., \& Kanzaki, M. 1998. Differences in soil properties of dry evergreen and dry deciduous forests in the Sakaerat Environmental Reserch Station. Tropics 8 (1/2): 61-80.

Sanchez, P. A. 1976. Properties and management of soils in the tropics, 52-95. Wiley-Interscience, New York.

Soil Survey Staff 1992. Keys to Soil Taxonomy, 5th ed. SMSS Technical Monograph No.19, 556 pp. Blackburg, Virginia.

Theng, C. S. 1993. Keys to Soil Classification in Sarawak. Technical paper 10, 47 pp. Soil Division, Department of Agriculture, Sarawak.

Van Wambeke, A. 1992. Soils of the Tropics: Properties and Appraisal, pp. 22-24. McGraw-Hill, Inc., New York.

Wood, T. W. W. \& Beckett, P. H. T. 1961. Some Sarawak soils. II. Soils of the Bintulu coastal area. J. Soil Sci. 12: 219-233.

Yamakura, T., Kanzaki, M., Itoh, A., Ohkubo, T., Ogino, K., Chai., E. O. K., Lee, H. S., \& Ashton, P. S. 1995. Topography of a large-scale research plot established within a tropical rain forest at Lambir, Sarawak. Tropics 5 (1/2): 41-56.

Received Sept. 7, 2000

Accepted Nov. 5, 2000

石塚悟史，櫻井克年, John Sabang, Joseph Jawa Kendawang, Hua Seng Lee マレーシアサラワク州における焼畑放棄地の土䁃特性

マレーシアサラワク州のバカム森林保護区 (BFR) 内の焼畑後の荒廃地において, 植林による生態系修復試 験が 1996 年から行われてきた。焼畑後の荒廃地における修復機能を評価するためには, まず現在の荒廃地 土壌の状態を明らかにする必要がある。本研究では, 荒廃地における土壌の形態学的, 物理化学的, 鉱物 学的, 荷電特性を調査した。

荒廃地における土壌の養分含量は極めて低く, 焼畑後の土壌侵食のため残存林内の土壌の次層程度であ

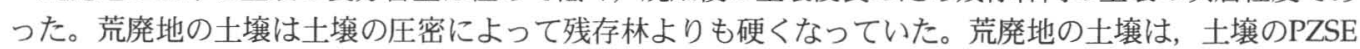
(荷電ゼロ点) が低いこと, 永久荷電をもつ 2:1 型粘土鉱物の流亡によって変異荷電粘土鉱物が卓越している こと, 酸化物含量が低いことから, 強風化土壌の特徵を示した。土壌の特性は, 土壌侵食後容易に劣化し, その場所の地形と水の動きによって改変されていると考えられた。一度植生が破壊されると，十分な降雨 と高い気温の状況下にあるが, 植生は本質的に肥沃度の低い土壤状態では容易に再生することはできない と思われた。 